\title{
A GYERMEKKÖZPONTÚ TANÍTÓ A JELENLEGI ELVÁRÁSOK TÜKRÉBEN
}

\section{THE CHILD-ORIENTED TEACHER, IN THE PERSPECTIVE OF THE CHALLENGES OF MODERN EDUCATION}

\author{
Szabó-Thalmeiner Noémi
}

\begin{abstract}
Bettering the personality of student teachers is one of the main goals in the training of teachers, but the way we should go about forming the teacher's character is a very frequently asked question. What are the most important qualities of a teacher? What should we reinforce in the students? This study tries to answer the following questions: Is the architype of the childoriented teacher fit for our modern, ever changing world, or do kids want something else out of their teachers? What do pupils want to see in teachers, and how do their opinions stack up against the opinions of students, who want to become teachers themselves? Based on the findings in our study, we can conclude, that the architype of the child-oriented teacher is well liked by pupils and students alike, although there are some differences in the qualities they'd like to see most: While pupils in elementary school mostly value someone, who understand them, is just and friendly to them, and is overall a great person first, teacher second, students put the expertise and experience of a teacher above personal qualities.
\end{abstract}

Keywords: teacher training, child-oriented teacher, teacher's personality, the competencies of a teacher.

\section{Bevezetés}

Jövendőbeli pedagógusokat nevelni nem kis kihívás, és nem kis felelősség. Hiszen nemcsak azokért a hallgatókért, az ő személyiségfejlődésükért felelünk, akiket közvetlenül oktatunk, képzünk, hanem hatásunk megsokszorozódik azokban a diákokban, akiket a mi általunk tanított pedagógusok a jövőben tanítani/nevelni fognak.

Pedagógusképző oktatóként folyamatosan foglalkoztatott a kérdés, hogy milyen pedagógusokat szeretnék nevelni? Milyen óvodapedagógusokat, tanítókat látnék szívesen az óvodákban, iskolákban.

A kérdés megválaszolása nem egyszerü feladat, hiszen sokrétü megközelítést tesz lehetővé. Megközelíthetem a kérdést a szakember szemszögéből, a meglévő tudományos eredményekre támaszkodva, azokat elemezve, feldolgozva. Áttekintve a témára vonatkozó szakirodalmat számos empirikus (pl. diákok megkérdezése, különböző nevelési stílusok hatásának kísérleti vizsgálata, stb.) és analitikus (pl. a pedagóguskép neveléstörténeti vizsgálata, pedagógusi kompetencialisták összehasonlító elemzése, stb.) jellegü kutatás eredményeire és az azok alapján megfogalmazott, a pedagógus személyiségére vonatkozó elméletre bukkanhatunk, mely támpontot nyújt munkánk során. (Sallai, 1996, Falus, 1998, 2001, 2006, Györgyiné Koncz, 2005, és mások)

Az elméleti kutatások eredményei mellett nem feledkezhetünk meg az oktatás-nevelés társadalmi meghatározottságáról sem, hiszen az aktuális és távlatokra kitekintő társadalmi elvárások számos követelményt fogalmaznak meg a pedagógussal szemben, különböző feladatok teljesítését várják el a gyakorló pedagógusoktól, melynek elvégzésére a hallgatókat fel kell készítenünk. Ezeket a 
szerepelvárásokat a közoktatási rendszer vezető-ellenőrzö-értékelő szervei közvetítik a pedagógusok számára.

Ugyancsak szakemberként, pedagógiai gyakorlatvezetőként, illetve a pedagógusi karrier betetőzését jelentő I. fokozati vizsgabizottságokban szerepet vállalva, érzékelhetem a pedagógiai valóság egy szeletkéjét, láthatom a pedagógus személyiségének hatását az általa vezetett gyermekcsoportra, s ez segít körvonalazni az eredményes pedagógus személyiségvonásait.

Az oktatói szerep betöltése mellett lehetőségem van szülóként is érzékelni a pedagógiai valóságot, mely új nézőpontot tesz lehetővé a pedagógus személyiségének körvonalazásában, esetleg megítélésében. Szülőként a szakember más szemszögböl látja a pedagógiai gyakorlatot, hiszen számára ezúttal a gyermeke fejlődése lesz a mérvadó, s ennek függvényében ítéli meg a pedagógus munkáját. Míg a szakember nézőpontját leginkább az értelem irányítja, a szülő szemszögéből a megközelítés már nemcsak értelmi, hanem érzelmi síkon is zajlik, hiszen gyermeke iránti szeretete vezérli, részesévé vált a pedagógiai folyamatnak. Ezért előfordulhat, hogy elvárásai elfogultabbak lesznek, viszont nem hagyhatóak figyelmen kívül, hiszen új perspektívákat nyithatnak meg az eredményes pedagóguskép kialakításában.

Az elözőekben bemutatott két nézőpont mellé én mindenképpen beilleszteném a gyermek szemszögét is, hiszen a szakembernek e szempontból is lehetősége van rálátni a megválaszolandó kérdésre azáltal, hogy élete jelentős korszakában a diák szemszögéből érzékelhette a pedagógiai valóságot, találkozhatott különböző pedagógus-személyiségekkel, melyek ilyen vagy olyan irányban befolyásolták élete alakulását. Nézetrendszerét mindenképpen befolyásolja, hogy milyen pedagógus példaképei voltak, az őt tanító pedagógusok viszonyulása, cselekedetei miként hatottak személyiségfejlödésére, milyen reakciókat váltottak ki gyermeki énjéből. Ehhez azonban az szükséges, hogy az idő elteltével se felejtsük el, milyen volt gyermeknek lenni.

A fentiekben bemutatott nézőpontok egymásra épülése, rendszerbe rendeződése egyre inkább azt az álláspontot erősítette meg bennem, hogy a pedagógusképzés során gyermekközpontú pedagógusokat szeretnék képezni, olyan óvodapedagógusokat és tanítókat, akik legfontosabb értéknek a gyermek fejlesztését tartják, s azt a szemléletmódot képviselik, hogy minden gyermek értéket hordoz önmagában, valamiben tehetséges, s a pedagógus feladata ennek felfedezése, illetve megerősítése. Hiszen nem szabad elfelejtenünk, hogy az oktatás-nevelés intézményrendszere elsősorban azt a célt szolgálja, hogy a gyermek fejlődését maximálisan biztosítsa, lehetővé téve a társadalomba való sikeres beilleszkedését. Ebben a folyamatban pedig a pedagógus személyisége is mérvadó, hiszen ő közvetíti a társadalom elvárásait a gyermek felé, az ő hozzáállásától, szakmai felkészültségétől is függ, hogy a tanuló a társadalmi értékekkel összhangban, kiegyensúlyozottan fogja-e elérni az adottságai által meghatározott maximális fejlettségi szintet.

A pedagógus személyiségére vonatkozó szakirodalom nagyon gazdag és részletesen felvázolja, milyen tulajdonságokkal, szakismeretekkel, pedagógusi készségekkel, képességekkel kell rendelkeznie egy eredményes pedagógusnak, melyek a pedagógusi kompetencia alapvető összetevői.

Jelen tanulmány keretein belül a tanító gyermekközpontúságának mibenlétét taglaljuk, a gyermekközpontú pedagógus néhány kvalitására fókuszáljuk figyelmünket összevetve a kor elvárásaival. Megvizsgáljuk, hogy a jelen kor elvárásainak megfelelhet-e egy gyermekközpontú pedagógus?

Ezt követően megvizsgáljuk, miként vélekednek a kisiskolás gyermekek, illetve a pedagógusképzésben résztvevő hallgatók a jó tanító személyiségéről, mennyire egyezik meg a gyermekek elvárása a tanítóképzős hallgatók elvárásaival, illetve, hogy a két vizsgált csoport által megrajzolt pedagógus-modell mennyire hordozza magán a gyermekközpontú pedagógus ismérveit. 


\section{Elméleti háttér bemutatása}

\subsection{A pedagógus személyisége}

A szerzők többnyire egyetértenek abban, hogy a pedagógusszakma a művészet és mesterség határán mozog, hiszen fontos szerephez jut benne az intuíció, a kreativitás, az improvizáció (ami a müvészet fő jellemzője), de vannak megtanulható elemei is: ismeretek, készségek, jártasságok (a mesterségre jellemző tulajdonságok). Mérlegre állítva a két jellemzőt a mesterség oldalára billen a mérleg nyelve (Sallai, 1996, Păun, 2002).

A fö kérdés tehát körülírni a pedagógus mesterség tartalmát. Sallai Éva (1996) meghatározása szerint a pedagógus mesterség ,azoknak a teoretikus háttérrel egybefogott és átszőtt, a pedagógus személyisége által meghatározottan, sajátosan strukturált, viselkedésben megnyilvánuló ismereteknek, jártasságoknak, készségeknek, képességeknek, attitüdöknek az összessége, amelyek a gyerekek fejlődésének optimális segítéséhez szükségesek" (Sallai, 1996, 11). Ennek a meghatározásnak a függvényében a pedagógus-mesterség alábbi tartalmi elemeit sorolja fel:

- Teoretikus háttér - ismeretek a világról, emberről, az ember fejlődéséről, tanulásról;

- Bizalomteli légkör megteremtésének a képessége - a feltétel nélküli elfogadás, az empátia és a hitelesség, melynek feltétele az önazonosság, az önelfogadás;

- Szaktudományi szempontból pontos, gazdag (szaktárgyi, lélektani, pedagógiai, stb.) tudás, tanítástechnikai készségek (Falus, 1998);

- Szerepviselkedés-biztonság: kommunikációs ügyesség, rugalmas és gazdag viselkedésrepertoár, gyors helyzetfelismerés, konstruktív helyzetalakítás, erőszakmentes, kreatív konfliktuskezelés;

- Együttmüködés igénye és képessége: diákokkal, szülőkkel és kollégákkal;

- Pedagógiai helyzetek, jelenségek elemzési képessége, a kompetenciahatárok biztos felismerése;

- Mentális egészség.

Külön jelentőséggel bír a reflektív gondolkodás, melyet ki kell alakítanunk a pedagógusokban, és melynek feltétele a nyitottság, a felelősségérzet és a nyíltszívüség.

Ugyancsak a pedagógus felkészültségének körülírására vállalkoznak a kompetenciaelmélet képviselöi is. Nagy József (2000) a személyiség vizsgálatakor négy kompetencia területet határol el: a kognitív, a személyes, a szociális és a speciális kompetenciát. A pedagógiai kompetencia a speciális kompetenciák fogalomkörébe tartozik, ezáltal motívumok, speciális képességek, szokások, minták, készségek és ismeretek meghatározott rendszere, melyek elengedhetetelen feltételét képezik a pedagógusi szakma gyakorlásának. Nagy József értelmezéséből kiindulva a speciális kompetenciák hatékonyságának feltétele a kognitív kompetencia megfelelő fejlettsége, illetve a személyes és legfőképpen a szociális kompetencia megfelelő fejlődése.

A pedagógiai kompetencia hasonló meghatározására bukkantunk a romániai szakirodalomban is. Mihai Diaconu (2002) szerint a pedagógiai kompetencia tág értelemben a pedagógusnak az a képessége, hogy a nevelési folyamat tényezőinek és törvényszerüségeinek alapos ismerete révén képes megoldani a pedagógiai helyzeteket. Szük értelmezésben a pedagógusnak az a a képessége, hogy megfelelő szinten tudja ellátni a szakma által indukált feladatokat.

Falus Iván (2005) a kompetenciát úgy határozza meg mint pszichikus képződmények olyan rendszerét, amely felöleli az egyénnek egy adott területre vonatkozó ismereteit, nézeteit, motívumait, gyakorlati készségeit, ezáltal lehetővé teszi az eredményes tevékenységet. A pedagógiai kompetencia tehát tudás, nézetek (pszichikailag alátámasztott feltételezések, propozíciók a világról, amelyeket igaznak vélünk, s melyek befolyásolják döntéseinket, ítéleteinket (Falus, 2001)), gyakorlati készségek ötvözete, mely lehetővé teszi, hogy a pedagógus egy adott területen sikeresen elláthassa feladatát. Fontos szerepet 
tulajdonít a diszpozíciónak is, annak, hogy a pedagógus elkötelezett legyen a fentiek alkalmazása iránt.

A pedagógiai kompetencia fogalmát összeveti a gyakorlati tudás - „,..olyan alapos tudás, amelyet a pedagógusok maguk alakítanak ki, s amely lehetővé teszi számukra a pedagógiai problémák felismerését, meghatározását, lehetséges megoldásaik elörelátását és, végül, megoldásukat. Azaz a gyakorlatra ténylegesen ható tudás." (Falus, 2005, 7) - fogalmával, s ennek eredményeként a pedagógiai kompetenciákat a gyakorlati tudás részének tekinti, egy-egy részterületen megnyilvánuló gyakorlati tudásnak.

A pedagógiai kompetenciákat az alábbi területekre vonatkoztathatjuk:

- Tantárgyi tudás

- Pedagógiai tartalmú tudás

- Tanulókkal és tanulással összefüggő tudás

- Oktatással és tanulásszervezéssel összefüggő tudás

- Az osztállyal és az iskolával összefüggö tudás

- Tantervvel, taneszközökkel összefüggő tudás

- A tanulók értékelésével összefüggő tudás

- A tanítás értékelésével összefüggő tudás

- Rutinok (adminisztráció).

Ahhoz azonban, hogy a pedagógus, illetve a pedagógushallgató tudja, milyen követelményeknek kell megfelelnie, szüksége van egy kompetencialistára, kidolgozott sztenderdekre, melyek objektíven és aprólékosan leírják azt a pedagógusi ismeretrendszert, viselkedést, hozzáállást, attitüdöt, mellyel egy gyakorló, illetve kezdő pedagógusnak rendelkeznie kell.

A sztenderdek tehát a kompetenciák szintjeit fogalmazzák meg, kellően specifikusak, explicitek és értékelhetők, világos alapot szolgáltatnak a képesítés megbízható, konzisztens odaítéléséhez (Falus, 2005).

A sztenderdek kialakítása, megfogalmazása komoly kutatómunkán alapszik. Az Amerikai Egyesült Államokban az INTASC (Interstate New Teacher Assessment Support Consortium) az alábbi sztenderdeket fogalmazta meg, melyek a pedagógusképzésben irányadók lehetnek:

1. A tantárgy ismerete

2. Az emberi fejlődés és tanulás ismeret

3. Az oktatás adaptálása az egyéni szükségletekhez

4. Többféle oktatási stratégia alkalmazása

5. Motivációs és tanulásszervezési készségek

6. Kommunikációs készségek

7. Tervezési készségek

8. A tanulás értékelése

9. Szakmai elkötelezettség és felelősség

10. Együttmüködés (Campbell és mtsai, 2000, idézi Falus és Kimmel, 2003, 62-63)

Romániában 1999-2004 között több empirikus kutatást végeztek annak érdekében, hogy feltárják a pedagógusképzés, pedagógus-továbbképzés és az oktatási vezetők képzésével szemben támasztott igényeket illetve a jelenlegi képzés megítélését. (Iucu és Pănişoara, 1999, 2000). Ezt követően az Oktatásügyi és Kutatási Minisztérium Tanárképzésért felelős Nemzeti Tanácsa 2001-2002 folyamán, igénybe véve James A. Kelly az amerikai NBPTS alapító elnöke és munkatársai segítségét, munkacsoportokat hozott létre a tanítói és a matematika tanári sztenderdek kidolgozása érdekében. A munkacsoport tagjai pedagógiai szakemberek, gyakorló pedagógusok, tanfelügyelők és iskolaigazgatók voltak az ország különböző részeiröl. A munkálatokat Románia Kormánya és a Világbank támogatta (Szabó-Thalmeiner, 2009). 


\subsection{A gyermekközpontú pedagógus}

A gyermekközpontúság fogalma mindenki számára más-más jelentést hordoz magában. Sokan tévesen úgy gondolják, hogy az a pedagógia gyermekközpontú, mely mindent megenged a gyermeknek, s a gyermek akarata az irányadó. Ezt a tévhitet szeretném eloszlatni.

A gyermekközpontúság szellemi gyökerei J. J. Rousseau francia filozófus pedagógiai jellegü munkáiban keresendők, melyek, bár nem reformálták meg kora oktatásügyét, de két évszázad elteltével kiindulópontként szolgáltak a reformpedagógiai irányzatok megalakulásánál. A herbartianizmus lemerevedett pedagógiai gyakorlata 1900-ban Ellen Keyt A gyermek évszázada címü könyvének megírására ösztönözte, melyben a svéd írónő arra hívja fel a figyelmet, hogy a gyermeket hagyjuk a maga módján szabadon kibontakozni, megfelelő környezeti feltételek biztosítása mellett. A mủ óriási port kavart pedagógiai berkekben, s elindította a gyermekközpontú reformpedagógiai irányzatok nagyszámú megjelenését (Waldorf-pedagógia, Freinet pedagógia, Maria Montessori pedagógiája, Jéna plan, Dalton terv, stb.), melyek reneszánsza napjainkban is megfigyelhető (Mészáros, Németh és Pukánszky, 2000).

A gyermekközpontú pedagógia kulcsa a pedagógus személyisége. Megfontolandóak Rousseau ezirányú gondolatai: „Mielőtt egy ember formálásába mernénk fogni, előbb embert kell csinálnunk magunkból. Önmagunkban kell megtalálni a példát, melyet neveltünk maga elé állít majd, előbb a magunk ura legyünk, ha a gyermek ura akarunk lenni.” (Rousseau, 1957 idézi Györgyiné Koncz, $2005,51)$ Ezt a gondolatot már Comeniusnál is megfigyelhetjük, hiszen a híres cseh-morva pedagógus az apostolokat állítja követendő példaként a nevelők elé: a nevelö legyen olyan, mint amilyenné kell alakítania növendékeit, és tudja, hogyan teheti tökéletessé tanítványait (Györgyiné Koncz, 2005, 4245).

A gyermekközpontú Lépésről-lépésre pedagógiai program alapvető tételként fogalmazza meg, hogy „minden ember egyszeri és megismételhetetlen egyéniség.” Ebből kiindulva Vekerdy Tamás (2004) gyermekpszichológus úgy látja, hogy a gyermekközpontú pedagógus fö feladata, hogy hozzásegítse a felnövő embert ahhoz, hogy azzá váljon, akivé lehet, s ennek érdekében biztosítsa azokat a körülményeket, melyekre szüksége van a megfelelő fejlődése érdekében.

Anélkül, hogy a tanító szaktárgyi tudásának jelentőségét lebecsülnénk Rudolf Steinerre (idézi Vekerdy, 2004) hivatkozva azt mondhatjuk, hogy a tanítónak "a gyerekben kell szakembernek lennie", illetve a vele való kapcsolattartás formájában. Ebböl a gondolatból kiindulva a gyermekközpontú tanítónak három fő területre kell koncentrálnia:

- gyermekismeretre - ismernie kell nagyon jól a gyermek életkori és egyéni sajátosságait (alapos fejlődéspszichológiai szaktudással kell rendelkeznie),

- odafigyelés a gyermekre - ez az egyes gyermek megismerésének alapvető feltétele. Az odafigyelés képessége feltételezi, hogy a tanító megfelelő szociális kompetenciával rendelkezzék (Nagy, 2000): legyen empatikus, megértő, hallgassa meg a gyermeket, tudja, mire van szüksége a gyermeknek, illetve

- a fejlődéshez szükséges biztonságos környezet kialakítására. Ennek alapvető tényezői a gyermekszeretet, az elfogadás képessége, a lelki nyugalom, mely szorongásmentes övezet kialakítását teszi lehetővé a gyermekek számára.

\subsection{A gyermekközpontú pedagógus a jelenlegi társadalmi elvárások tüikrében}

A továbbiakban, a gyermekből és a társadalom aktuális kihívásaiból kiindulva, tekintsük át, milyen feladatai vannak a jelenkor tanítójának, s lássuk, hogyan nyilvánulhat meg a gyermekközpontúság az elvárt feladatok teljesítése során.

Kicsit túllépve, illetve kiegészítve Vekerdy Tamás megállapítását a tanító szerepköréhez két fontos feladatot kapcsolhatunk: 
1. egyfelől, egy szervezett csoport vezetőjeként a csoportcél elérését kell biztosítania. Az osztály azért szerveződött, hogy minden gyermek személyisége megfelelően fejlődjön, ennek feltételeit kell az osztálytanítónak megteremtenie.

2. másodsorban biztosítania kell a csoport fennmaradását, hiszen ez is nevelö eszköz lehet a tanító kezében. Ennek érdekében fejlesztenie kell a rábízott közösséget.

Az első feladat keretén belül induljunk ki a kor aktuális kihívásaiból, melyek hozzájárultak a tanulás folyamatának átértelmezéséhez. Az előző korokhoz képest megnövekedett az az információmennyiség, mely hozzáférhetővé vált a diákok számára. Ma már nem a tanító az információ egyedüli birtokosa, a gyermek különböző színes enciklopédiákból, könyvekből, televíziós csatornák müsoraiból, Internetről számos információ birtokába jut, melyet szivacsként szív magába. Ezért a tanító fö feladata már nem az információközlés, hanem megtanítani a diákoknak, hogyan szelektáljanak a rájuk zúduló információk tömkelegéböl, hogyan emeljék ki a lényeget, illetve hogyan rendszerezzék tudásukat. Láthatjuk, hogy az előző korok pedagógiájához képest a hangsúly áttevődött a tanítás folyamatáról a tanulás folyamatára. A tanítónak az oktatási folyamat megtervezésekor a gyermekre kell koncentrálnia: feltárja a diákok előzetes ismereteit a tanult témával kapcsolatban, segít kiemelni a lényeges információkat, majd irányítja a rendszerezés folyamatát. Ezáltal már nemcsak egyszerü ismeretelsajátításról beszélünk, hanem a kognitív tevékenységhez szükséges képességek kialakításáról, fejlesztéséről (1. ábra).

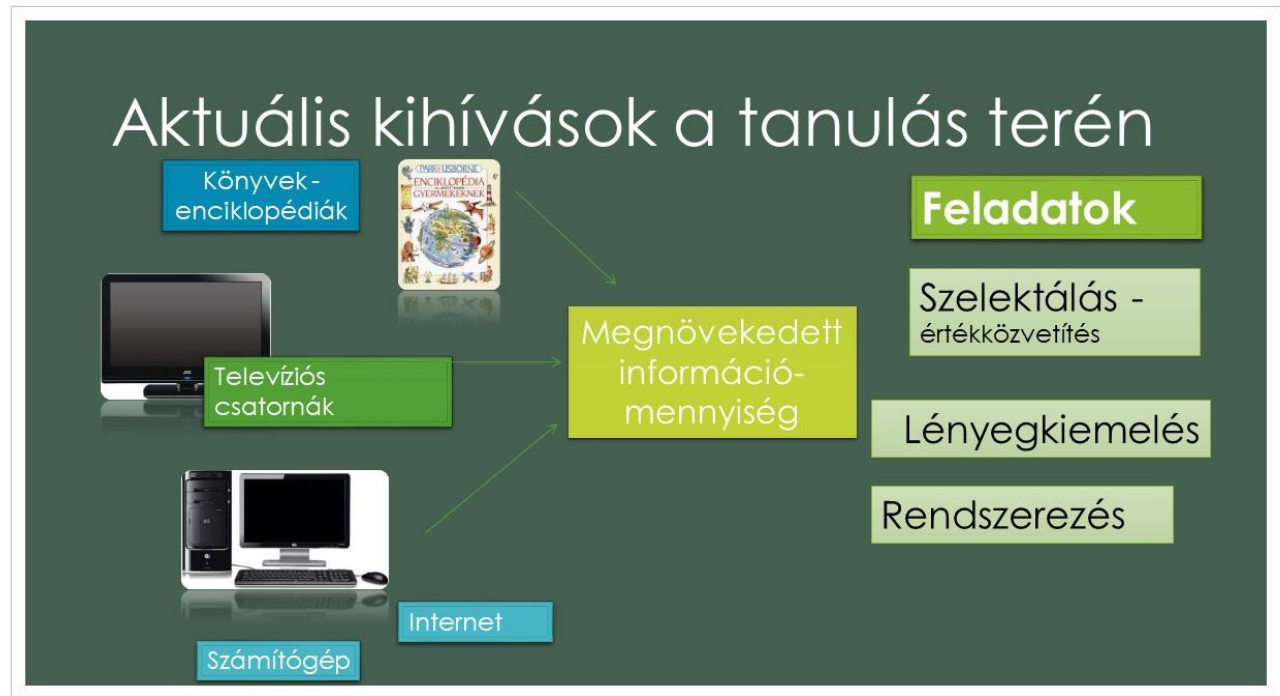

1. ábra. Aktuális kihívások a tanulás terén

A hangsúlyeltolódás más szemléletmódot igényel a pedagógus részéről. A tanár segítő-támogató szerepkört tölt be, segíti a tanulók ismeretelsajátítási folyamatát. Ennek a szerepkörnek a betöltése az alábbi feladatokat igényli a tanítótól:

1. alapozzon a gyermek érdeklődésére, ismerje meg a gyermek érdeklődési területeit,

2. tartsa fenn az érdeklődést, a gyerekek tanulás iránti motivációját,

3. teremtsen biztonságos légkört az osztályban,

4. tegye lehetővé, hogy a gyermek maga fedezze fel az információkat, tevékenykedtesse,

5. figyeljen oda minden gyerekre, alkalmazza a differenciálást, mellyel biztosíthatja az eltérő fejlődési ütemmel rendelkező diákok fejlődését.

Hogyan érhetjük ezt el? A konstruktivizmus és a cselekvés pedagógiájának tanulásszemlélete nyújt ebben segítséget (Nahalka, 1998). A tanulók önálló tevékenységére alapoz, melynek hatékonysága érdekében törekszik a tanulás iránti pozitív motiváció kialakítására. A tanítónak széles módszertani repertoárral kell rendelkeznie, a hagyományos oktatási módszereken kívül ismernie kell számos interaktív módszert is, így lehetővé válik a tanulók tevékeny bevonása a tanulási folyamatba. A 
projekt alapú oktatást alkalmazza, mely lehetőséget teremt a csoporton belüli problémaalapú tanulásra, a differenciálásra.

A második feladatkör a közösségfejlesztésre vonatkozik, s a megváltozott világ ezen a téren is számos kihívást tartogat a pedagógus számára. A változás fő oka leginkább a határok átjárhatóságának, a megnövekedett utazási kedvnek, a munkavállalási szokások megváltozásának, az európai dimenzió megjelenésének köszönhető. A mostani világunkra a sokszínűség jellemző, a különböző nemzetek, nemzetiségek egymás mellett élése tapasztalható, keverednek a nyelvek, a sok esetben eltérő értékeket képviselő vallások, társadalmi-gazdasági egyenlőtlenségek tapasztalhatók. Ezek az új jelenségek az értékek sokszínüségét, a modernizáció pedig az értékek tobzódását idézték elő, megnövekedett a konfliktusok száma, illetve egyre több az elöítélet is. Ebben a világban különösen fontos a szociális kompetencia kialakítása, ezért a tanítónak a szilárd értékrend kialakítására, a másság elfogadására és az erőszakmentes konfliktuskezelésre kell nevelnie diákjait (1. 2. ábra).

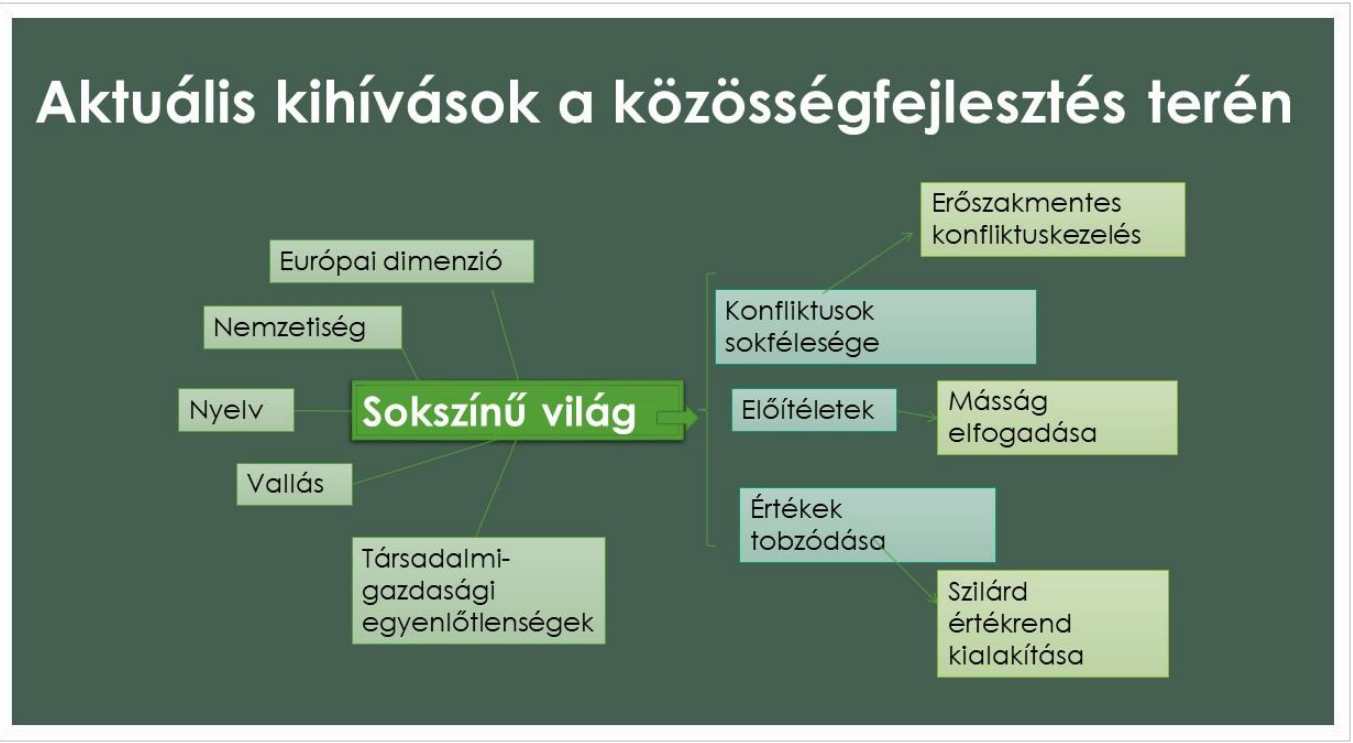

2. ábra. Aktuális kihívások a közösségfejlesztés terén

A tanító példaértékü magatartása követendő modell a gyermekek számára, hiszen az osztálybeli viszonyulása, cselekedetei lesznek e téren meghatározóak: ha odafigyel minden gyermekre, meghallgatja őket, értékeli pozitívumaikat, tiszteli őket, segítőkész, együttmüködő, erőszakmentesen kezeli a konfliktushelyzeteket, a gyermekek is ezt a magatartást veszik át és követni fogják. Ehhez viszont elengedhetetlen a jó tanító-diák kapcsolat megléte, melynek alapja a kölcsönös tiszteleten alapuló tekintély, illetve a szeretet.

Amint a rövid elméleti összefoglalóból is kiderül a pedagógus gyermekközpontú felfogása összhangban van a jelenkor társadalmi elvárásaival, hiszen mindkét fő feladata teljesítése érdekében oda kell figyelnie az egyes gyermekek személyiségfejlődésére, tanulási szokásaira, kulturális sajátosságaira, empatikusnak, nyitottnak, együttmüködőnek kell lennie A mai korra jellemző az egyéniség megnyilvánulása, melynek fejlesztése csakis differenciáltan, megfelelő cselekedtető módszeregyüttest alkalmazva valósulhat meg.

\section{A kutatás bemutatása}

A fenti elméleti tételekből kiindulva arra voltunk kíváncsiak, hogy a gyermekközpontú pedagógusra jellemző tulajdonságok mennyire fontosak a gyermekek, és a jövendőbeli pedagógusok számára? Amint az elméleti bevezetőből is kitünik, a pedagógus szakma eredményes gyakorlásához számos ismeretre, készségre, képességre, jártasságra, megfelelő hozzáállásra, személyiségbeli tulajdonságokra van szükség, melyek szerepe vitathatatlan. Viszont ezen tényezök meglétének szükségességét, vajon milyen mértékben ítélik meg a tanulók, illetve a pedagógusi szakma gyakorlására készülő egyetemi 
hallgatók? Előtérbe kerülnek a fontossági sorrendben a gyermekközpontú pedagógusra jellemző tulajdonságok?

Vizsgálatunk során tehát arra a kérdésre kerestük a választ, hogy milyen elvárásokat támasztanak a kisiskolások, illetve a tanítóképzős hallgatók az ideális tanítóval szemben. Melyek azok a tulajdonságok, melyeket leginkább fontosnak tartanak egy jó pedagógus esetében, mennyire rajzolódik ki elvárásaikból a gyermekközpontú tanító modellje? Vajon a tanítóképzős hallgatók és a kisiskolások véleménye megegyezik, hasonlóan gondolkodnak az ideális tanítóról?

A kutatás elején feltételeztük, hogy:

1. Nemtől, településtől és iskolától függetlenül a tanulók azonos, a gyermekközpontú pedagógusra jellemző tulajdonságokat, várják el leginkább egy tanítótól.

2. A kisiskolások által fontosnak tartott tulajdonságok megegyeznek azokkal a tulajdonságokkal, melyeket a tanítóképzősök is gyerekként értékeltek saját tanítójukban.

3. Hallgatóként a tanítóképzősök elvárásai módosulnak olyan formában, hogy a tanító szaktudását helyezik majd elötérbe.

4. A hallgatók szakválasztását kutatva feltételeztük, hogy a pedagógusi szakma megválasztása többnyire már kisgyermekkorban megtörténik.

A vizsgálat során az induktív, összefüggésfeltáró kutatási stratégiát alkalmaztuk, módszerként az írásbeli kikérdezést használtuk, melynek eszközeként két kérdőívet dolgoztunk ki, egyet a 3-4. osztályos diákok, egyet pedig a tanítóképzős hallgatók részére. Az adatok feldolgozása SPSS programban történt, relatív és abszolút gyakoriságot, szignifikancia vizsgálatot végeztünk, illetve korrelációkat tártunk fel különböző változók között.

A vizsgált minta a Babeş Bolyai Tudományegyetem Szatmárnémeti Kihelyezett Tagozatának tanítóképzős hallgatóit (38 hallgató), illetve Szatmár megyei III. és IV. osztályos diákokat foglal magába (124 tanuló).

A kisiskolások kérdőívét 3-4. osztályos diákok töltötték ki két városközponti iskolában, melynek egyike teológiai profilú iskola, illetve egy vidéki iskolában összesen 60 fiú és 64 lány. A kutatásban résztvevő gyermekek 47,6\%-a harmadik osztályos, 52,4\%-a negyedik osztályos tanuló, 71,8\%-uk városon, 28,2\%-uk pedig vidéken él. (1. 1. táblázat)

1. táblázat: A kisiskolások mintájának nem és lakhely szerinti megoszlása

\begin{tabular}{|l|c|c|c|}
\hline & Város & Vidék & Összesen \\
\hline Fiú & $48(80 \%)$ & $12(20 \%)$ & 60 \\
\hline Lánynt & $41(64,1 \%)$ & $23(35,9 \%)$ & 64 \\
\hline Összesen & $89(71,8 \%)$ & $35(28,2 \%)$ & 124 \\
\hline
\end{tabular}

A vizsgálatban résztvevő tanítóképzős hallgatók (38 hallgató) a Babeş-Bolyai Tudományegyetem Szatmárnémeti Kihelyezett Tagozatának nappali szakos hallgatói, 28,9\%-uk elsőéves, 28,9\%-uk másodéves, 42,1\%-uk harmadéves hallgató, 42,1\%-uk városon, 57,9\%-uk vidéken él, mindannyian nők. (1. 2. táblázat)

2. táblázat: Az egyetemisták mintájának évfolyam és lakhely szerinti megoszlása

\begin{tabular}{|c|c|c|c|}
\hline & Város & Vidék & Összesen \\
\hline 1. éves & $3(27,3 \%)$ & $8(72,7 \%)$ & 11 \\
\hline 2. éves & $5(45,5 \%)$ & $6(54,5 \%)$ & 11 \\
\hline 3. éves & $8(50 \%)$ & $8(50 \%)$ & 16 \\
\hline Összesen & $16(42,1 \%$ & $22(57,9 \%)$ & 38 \\
\hline
\end{tabular}


A továbbiakban tekintsük át a kutatás elején feltett kérdések mentén, hogyan vélekednek az ideális tanítóról megkérdezett kisiskolások és hallgatók. A kérdőív elején az elméleti részben bemutatott pedagógusi kompetenciák függvényében egy tulajdonságlistát állítottunk össze. A tulajdonságok száma és megfogalmazása kicsit eltért a kisiskolások és egyetemi hallgatók kérdőívében, mivel a kitöltő személyek eltérő életkora ezt indokolttá tette. A megkérdezett tanulók feladata az volt, hogy az adott tulajdonságlista elemeiből válasszanak ki öt tulajdonságot, mely szerintük az ideális tanítót jellemzi. Az átlagpontértékek 1 és 2 között helyezkednek el, minél kisebb pontszámot kapott egy tulajdonság, annál fontosabbnak tartották a diákok. A hallgatók feladata kicsit bonyolultabb volt, nekik a megadott húsz felsorolt tulajdonságot kellett rangsorolniuk. A tanulók és a hallgatók számára megadott tulajdonságlistában szerepeltek a gyermekközpontú pedagógusra jellemző tulajdonságok: kedves, gyermekszerető, megértő/empatikus, nyitott, bátorít, segítőkész.

Amint a 3. táblázatból kiderül, a kisiskolások számára a legfontosabb, hogy a tanító kedves, megértő $(1,35)$ illetve, hogy okos $(1,40)$ legyen. Legkevésbé tartották fontosnak azt, hogy csend legyen az óráin $(1,93)$, illetve, hogy jó minősítést adjon $(1,90)$. A gyermekközpontú pedagógus sajátossága, hogy odafigyel a gyermekre, megfelelően motiválja, hogy képességeihez mérten a maximumot hozza ki a gyermek önmagából. A tanulók fontosnak tartják ezeket a tulajdonságokat, hiszen a bátorítást, dicséretet, illetve a segítőkészséget 4. illetve 7 helyre rangsorolták. Ugyancsak fontosnak tartják, hogy igazságos (3. hely) legyen, hogy betartsa a szavát (6. hely) és ne kivételezzen (8. hely). Az oktatással kapcsolatos főbb készségek, melyekre a képzés során hangsúlyt fektetünk: jól magyaráz (5. hely), játékos órákat tart (8. hely), érdekes órákat tart (10. hely) hátrébb kerültek a ranglistán, mint a nevelés, motiválás szempontjából előnyösebb tulajdonságok. Meglepő, de a kisiskolások számára elég fontos, hogy a tanító szigorú és vicces legyen, a vizsgált minta 18,5\%-a említette meg e két tulajdonságot.

3.táblázat: A kisiskolások által fontosnak tartott tulajdonságok rangsora

\begin{tabular}{|c|l|c|c|}
\hline Rangsor & Tulajdonság & Átlagérték & Gyakoriság \\
\hline \multirow{2}{*}{} & Kedves & 1,35 & $64,5 \%$ \\
\cline { 2 - 4 } & Megértő & 1,35 & $64,5 \%$ \\
\hline 2. & Okos & 1,40 & $59,7 \%$ \\
\hline 3. & Igazságos & 1,57 & $42,7 \%$ \\
\hline 4. & Sokat bátorít és dicsér & 1,63 & $36,3 \%$ \\
\hline 5. & Jól magyaráz & 1,65 & $34,7 \%$ \\
\hline 6. & Betartja a szavát & 1,73 & $26,6 \%$ \\
\hline 7. & Segítőkész & 1,76 & $23,4 \%$ \\
\hline 8. & Nem kivételez & 1,79 & $21 \%$ \\
\cline { 2 - 4 } & Játékos órákat tart. & 1,79 & $21 \%$ \\
\hline 9. & Szigorú & 1,81 & $18,5 \%$ \\
\cline { 2 - 4 } & Vicces & 1,81 & $18.5 \%$ \\
\hline 10. & Érdekes órákat tart & 1,82 & $17,7 \%$ \\
\hline 11. & Szépen öltözködik, csinos & 1,85 & $14,5 \%$ \\
\hline 12. & Ötletes & 1,87 & $12,9 \%$ \\
\hline 13. & Felnézek rá / Fel lehet rá nézni & 1,88 & $11,3 \%$ \\
\hline 14. & Mindig jó minösítést ad & 1,90 & $9,7 \%$ \\
\hline 15. & Csend van az óráin & 1,93 & $6,5 \%$ \\
\hline & Összesen & & 124 \\
\hline
\end{tabular}

Megvizsgáltuk a fenti adatokat település, nem és intézmény függvényében is, de szignifikáns eltérést nem találtunk. Viszont életkoronként összevetve a 3. és 4. osztályos diákok válaszait szignifikáns különbséget tapasztalhattunk az egyes tulajdonságok mentén: a negyedik osztályos tanulóknak kevésbé volt fontos, hogy a tanító csinos, megértő, szigorú legyen, viszont előbbre helyezték, hogy a tanító jó minősítést adjon, jól magyarázzon és érdekes órákat tartson (1. 4. táblázat).

4. táblázat: A tulajdonságok megítélésenek átlaga kisiskolások osztályok szerinti megoszlásában

\begin{tabular}{|l|l|c|c|}
\hline & 3 osztály & 4 osztály & Szignifikancia $\mathrm{p}$ \\
\hline Csinos & 1,76 & 1,93 & $\mathrm{p}<0,05$ \\
\hline
\end{tabular}




\begin{tabular}{|l|l|l|l|}
\hline Megértő & 1,18 & 1,50 & $\mathrm{p}<0,01$ \\
\hline Szigorú & 1,72 & 1,89 & $\mathrm{p}<0,05$ \\
\hline Jó minősítést ad & 1,96 & 1,84 & $\mathrm{p}<0,05$ \\
\hline Jól magyaráz & 1,76 & 1,55 & $\mathrm{p}<0,05$ \\
\hline Érdekes órákat tart & 1,91 & 1,73 & $\mathrm{p}<0,01$ \\
\hline
\end{tabular}

A táblázatba foglalt értékek alapján megállapíthatjuk, hogy az életkor növekedésével a diákok számára egyre fontosabbakká válnak az oktatás minőségével kapcsolatos eredményes pedagógusi jártasságok, viselkedések, és háttérbe szorulnak egyes külső tényezők (pl. kinézet), illetve a személyiségbeli tényezők. Ez az eredmény előrejelzője lehet egy tendenciának, miszerint a tanulás, ismeretelsajátítás minősége egyre fontosabbá válik az életkor előrehaladtával, míg a kisebb gyermekek számára a biztonságos tanulói környezet a legfontosabb, az idősebb tanulóknál az eredményes tanuláshoz szükséges feltételek kerülnek előtérbe. Ezt a tendenciát támasztja alá Nikitscher Péter (2015) vizsgálata is, melyet középiskolások körében végzett. Ebből a kutatásból kiderül, hogy a 9.-11. évfolyamon tanuló diákok számára a legfontosabb a tanár szaktárgyi tudása, illetve, hogy tudását közérthetően adja át diákjainak.

Korrelációvizsgálat során kiderült, hogy bizonyos tulajdonságok említése között összefüggés tapasztalható: azok a kisdiákok, akiknek fontos, hogy a tanító megértő legyen, fontosnak tartják hogy a tanító szigorú $(\mathrm{p}<0,05)$, illetve igazságos $((\mathrm{p}<0,05)$ is legyen. A jó minősítést fontosnak tartó gyerekek esetében a tanítónak csendet kell tartania $(\mathrm{p}<0,01)$, de a játékos órákat is fontosnak tartják $(\mathrm{p}<0,01)$. Ugyancsak együttjáró két jó tulajdonsága a pedagógusnak ha ötletes és vicces $(\mathrm{p}<0,05)$.

A tanítóképzős hallgatók véleménye alapján összeállított tulajdonságrangsor kicsit eltér a kisiskolásokétól, s ez többnyire a szakmára való tudatos felkészülésnek tulajdonítható, illetve annak, hogy ők már más szemszögből tekintenek az oktató-nevelöi munkára. (1. 5. táblázat) Lehetséges magyarázat lehet azonban az életkor is.

Megfigyelhető, hogy a tanítóképzősök számára a legfontosabb, hogy jó szaktudással rendelkezzenek és az, hogy szeressék a gyermekeket. Legkevésbé fontos számukra, hogy a tanító csinos (20. hely) és szigorú (19. hely) vagy humoros (18. hely) legyen. Megfigyelhető, hogy az oktatással közvetlen kapcsolatban lévő készségek, jártasságok, tulajdonságok előnyösebb rangsort foglalnak el, mint a kisiskolások esetében. A tanítóképzősök számára fontosabb, hogy a tanító érdekes órákat tartson (4. hely), jól magyarázzon (5. hely), kreatív legyen (6. hely), változatos módszereket használjon (8. hely) mint az, hogy bátorítson (10. hely), segítőkész, empatikus, nyitott legyen (11-13. hely). A fegyelmezés és a tekintélyelvüség illetve az értékelés is háttérbe szorul (14, 16, 17 hely).

5. táblázat: A tanítóképzős hallgatók által fontosnak tartott tulajodnságok rangsora

\begin{tabular}{|c|l|}
\hline Rangsor & Tulajdonság \\
\hline 1. & Jó szaktudással rendelkezik. \\
\hline 2. & Gyermekszeretö. \\
\hline 3. & Igazságos. \\
\hline 4. & Érdekes órákat tart. \\
\hline 5. & Jól magyaráz. \\
\hline 6 & Kreatív \\
\hline 7 & Kedves \\
\hline 8 & Változatos módszereket használ \\
\hline 9 & Következetes \\
\hline 10 & Bátorít \\
\hline 11 & Segítőkész \\
\hline 12 & Empatikus \\
\hline 13 & Nyitott \\
\hline 14 & Jól fegyelmez \\
\hline 15 & Hiteles \\
\hline 16 & Tekintélye van. \\
\hline
\end{tabular}




\begin{tabular}{|l|l|}
\hline 17 & Jól osztályoz \\
\hline 18 & Humoros \\
\hline 19 & Szigorú \\
\hline 20 & Csinos \\
\hline
\end{tabular}

Vizsgálatunk során összehasonlítottuk évfolyamonként és településenként is a hallgatók által megállapított rangsorokat.

Településenként vizsgálva a hallgatók által adott válaszokat csak a jó szaktudás tekintetében találtunk szignifikáns eltérést $(\mathrm{p}=0,028)$, a városon élő hallgatók ezt a tulajdonságot többre értékelték $(2,38)$ a vidéken élő hallgatóknál (5), bár mindkét csoporthoz tartozó diák előre helyezte a ranglistán, amint ezt a végső, összesített rangsor is mutatja (1. 5. táblázat).

Továbbá azt tapasztalhattuk, hogy szignifikáns különbségek mutatkoztak meg egyes tulajdonságok megítélésénél évolyamonként: a harmadéves hallgatók sokkal fontosabbnak tartották, hogy a tanító empatikus és hiteles legyen, mint első két évfolyambeli társaik, míg az első és másodéves hallgatók azt értékelték jobban, ha a tanító jól fegyelmez. Az elsőéves hallgatók a tanító humorosságát is jobban értékelték, mint nagyobb évfolyamra járó társaik, illetve a másodéves hallgatók számára fontosabb volt az, hogy a tanító osztályozzon jól. (1. 6. táblázat).

6. táblázat: Egyes tulajdonságok rangátlaga a tanítóképzős hallgatók évfolyamonkénti megoszlásában

\begin{tabular}{|l|l|l|c|c|c|}
\hline & Összérték & 1. évfolyam & 2. évfolyam & 3. évfolyam & Szignifikancia \\
\hline Empatikus & 10,63 & 14,55 & 11,55 & 7,31 & $\mathrm{p}=0,002$ \\
\hline Hiteles & 12,42 & 15,64 & 14,27 & 8,94 & $\mathrm{p}=0,002$ \\
\hline Jól osztályoz & 13,87 & 14,09 & 11,36 & 15,44 & $\mathrm{p}=0,031$ \\
\hline Jól fegyelmez & 12,21 & 9,55 & 11,18 & 14,75 & $\mathrm{p}=0,006$ \\
\hline Humoros & 14,13 & 11,45 & 16,91 & 14,06 & $\mathrm{p}=0,005$ \\
\hline
\end{tabular}

A fenti eredményeket figyelembe véve, felmerült a kérdés, hogy évfolyamonként változik-e a hallgatók rangsorolása. Az első három tulajdonság tekintetében eltéréseket tapasztalhattunk: az első és másodéves hallgatók rangsorában a jó szaktudás és a gyermekszeretet áll az első két helyen, az összesített eredményekkel megegyezően, viszont a harmadéves hallgatóknál a sorrend megfordul, előbbre helyezik a gyermekszeretetet a jó szaktudásnál, illetve harmadik helyre rangsorolják az empatikus tulajdonságot, mely az összesített rangsorban a 12. helyet foglalja el. A másodévesek listáján a harmadik helyen az összesített rangsornak megfelelően az igazságosság szerepel, viszont az elsőévesek harmadik legfontosabb tulajdonságnak azt nevezték meg, hogy a tanító tudjon jól magyarázni. (1. 7. táblázat). Az említett különbségek nagy valószínüséggel annak tulajdoníthatók, hogy a hallgatók a képzés különböző szintjein állnak. Az első és másodéves hallgatók a pedagógiai gyakorlatuk során még csak megfigyelési gyakorlaton vettek részt (a felmérés tanév elején készült), míg a harmadéves hallgatóknak már volt alkalmuk a katedra másik oldaláról is megtapasztalni az oktatást. Mindez arra enged következtetni, hogy a képzésnek jelentős hatása lehet a tanítóképzős hallgatók nézeteinek alakulására, jelen esetben azt mondhatjuk, hogy segítheti a gyermekközpontú szemléletmód kialakítását..

7. táblázat: A “dobogós” tulajdonságok a tanítóképzős hallgatók évfolyamonkénti megoszlásában

\begin{tabular}{|l|l|l|l|c|}
\hline & Összesített rangsor & 1. évfolyam & \multicolumn{1}{|c|}{ 2. évfolyam } & 3. évfolyam \\
\hline 1 & Jó szaktudás & Jó szaktudás & Jó szaktudás & Gyermekszerető \\
\hline 2 & Gyermekszerető & Gyermekszerető & Gyermekszerető & Jó szaktudás \\
\hline 3 & Igazságos & Jól magyaráz & Igazságos & Empatikus \\
\hline
\end{tabular}

A kisiskolások és tanítóképzős hallgatók válaszait összevetve megfigyelhetjük, hogy a kisiskolások szerint a jó tanító elsősorban kedves és megértő, s ezt követi az okossága. A tanítóképzős hallgatók esetében a sorrend megfordul, a tanító elsősorban legyen jó szaktudású és másodsorban gyermekszerető́. A kedves, illetve a megértö/empatikus tulajdonság az összesített 20-as tulajdonságlistában a 7. illetve 12. helyre került. Viszont a harmadéves hallgatók rangsorolását figyelembe véve megállapíthatjuk, hogy a képzés végére az empátia is előtérbe kerül. 
Nagyjából azonosan fontosnak ítélték meg a kisiskolások és az egyetemisták, hogy a tanító legyen igazságos (4. illetve 3. helyre tették a rangsorolásban), illetve, hogy magyarázzon jól (6. illetve 5. hely), viszont a kisiskolások fontosabbnak ítélték meg, hogy egy tanító bátorítsa a diákot (5 hely, szemben az egyetemisták 10 rangjával), mint hogy érdekes órát tartson (10. rang a diákoknál, 4 hely az egyetemistáknál).

Érdekes módon sem a diákok, sem az egyetemisták nem tartották fontosnak, hogy a tanító jó minösitést adjon, illetve, hogy csendet tartson az órán, illetve közepesen fontosnak ítélték meg, hogy játékos, változatos módszereket használjon (8. hely mindkét rangsorban).

További eltérések figyelhetőek meg az ötletes/kreatív tulajdonságnál, a hallgatók számára ez a tulajdonság fontosabb (12. hely a diákoknál, 6. az egyetemistáknál). A tanító kinézete fontosabb a gyerekek, mint a hallgatók számára (11 - 20 hely), illetve meglepő módon a gyerekek inkább értékelik a tanító szigorúságát, mint az egyetemisták. „Ha szigorú, az jó, mert azt akarja, hogy mindent megtanuljunk és okosak legyünk.” (írja az egyik 3. osztályos tanuló). Ugyancsak fontosabbnak tartják a gyerekek, hogy a tanító humoros legyen (9. hely), mint a hallgatók (18. rang).

Érdemes megemlíteni pár gyermeki megfogalmazást is, melyet arra a kérdésre adtak, hogy milyen tanítót szeretnének:

A tanító: „Kezesbárány, simogató, bársonyos keze végigszalad a gyerekek arcán és kedvesen mosolyog. Így a gyerekek szíve megtelik örömmel és melegséggel.” „Legyen türelmes, hogy a gyerekek minden nap szeressék.” „Legyen megértő, hogy mi még fiatalok vagyunk.” „Nemcsak kedves, hanem tudnia kell, hogy kell megtartani egy vicces órát.” „Legyen benne szeretet, mert ha van, akkor mi is fogjuk szeretni.” „Biztonságban érzem magam mellette.” „Nekem mindegy, hogy milyen egy tanító néni, csak szeressen minket." „Órákon legyen minden gyereknek jókedve, s sohase jöjjön senki szomorúan iskolába.”

Bár a tulajdonságok rangsorolásánál eltérés tapasztalható a kisiskolások és az egyetemisták véleménye között, amikor arra kérdeztünk rá, hogy miért szerették, illetve miért nem szerették a tanítóképzős hallgatók tanítóikat, ugyanazokat a tulajdonságokat nevezték meg elsősorban, amit a kisiskolások: szerették a kedves, megértő, igazságos, segítőkész, becsületes, határozott tanítót, aki tudott fegyelmezni is és intelligens volt, odafigyelt minden gyerekre és szerette őket. Kirándulásokat szervezett, kreatív, ötletes és jó problémamegoldó volt, szívvel-lélekkel végezte a munkáját. Ha jól megfigyeljük a felsorolást az elméleti részben bemutatott gyermekközpontú pedagógus képe rajzolódik ki lelki szemeink előtt. Nem szerették viszont, ha a pedagógus stresszes volt, türelmetlen, túl szigorú, túl engedékeny volt, nem volt kedves, kivételezett, illetve nem alacsonyodott le a gyermekekhez. A hallgatók 50\%-a példaként tekint mai napig is tanítójára.

A tanítóképzős hallgatók pályaválasztási motivációját vizsgálva azt tapasztaltuk, hogy jelentős hányaduk, 74\%-uk már gyermekkorában eldöntötte, hogy pedagógus lesz, és azért választotta ezt a szakot. Megnyugtató, hogy további $18 \%$-uk is belső indíttatástól vezérelve jelentkezett erre a szakra, mivel szeret a gyermekekkel foglalkozni. Csak a hallgatók $8 \%$-a választotta a szakot elsősorban azért, mert ez a szak volt helyben.

Kíváncsiak voltunk, hogy a mostani világban, szeretnének-e a gyerekek pedagógusok lenni? Azt tapasztalhattuk, hogy 4\%-uk választaná az óvodapedagógusi vagy tanítói szakot, illetve 6\%-uk lenne tanár. Ugyancsak 10\%-uk lenne sportoló, illetve azt követően edző.

\section{Következtetések, összegzés}

$\mathrm{Az}$ empirikus vizsgálat eredményei is alátámasztják elképzelésünket, hogy a gyermekközpontú szemléletmód átadása, kialakítása révén hallgatóink jó tanítókká válhatnak, hiszen a gyermekeknek elsősorban kedves, megértő és okos tanítóra van szükségük, aki bátorítja őket. Aki lehet humoros is, de ugyanakkor szigorú is.

A hipotézisek mentén haladva megállapíthatjuk, hogy a kisiskolások nemtől, iskolatípustól, településtől függetlenül hasonló elvárásokat támasztanak a jó tanítóval szemben: fontos számukra, 
hogy a tanítójuk megértő, kedves, igazságos legyen, majd ezt követően okos. Bár gyermekkorukban a tanítóképzős hallgatók is hasonlóképpen vélekedtek, mint a mai kisiskolások, a katedra másik oldalára kerülve már más szemszögböl fogalmazzák meg elvárásaikat a jó tanítóval szemben: fontossá válik számukra a szaktudás, hogy megfelelő képzettséggel szervezzék meg az oktató-nevelö folyamatot, de ugyanakkor nagyon fontosnak tartják a gyermekek iránti szeretetet is. E két tényező egymásrahatása révén tudatos, gyermekközpontú tanítókká válhatnak. A tanítóképzős hallgatók véleményéből kiderült az is, hogy az oktatás megszervezése, kivitelezése, a változatos módszerek használata, érdekfeszítő órák megtartása számukra fontosabb, mint a különböző személyiségbeli tényezők, melyek a nevelés alapját képezik: kedvesség, empatikusság, nyitottság, következetesség, hitelesség. Ez a sorrendiség valószínüleg a saját elvárásaikból is fakad, hiszen ezt várják el ők is leginkább oktatóiktól. Figyelemreméltó adat viszont, hogy a képzés vége felé érve a hallgatók szignifikánsan fontosabbnak tartják, hogy a tanító empatikus, gyermekszerető legyen. További kutatás tárgyát képezheti tehát az a tény, hogy mennyire befolyásolja a képzés a hallgatók ideális tanítóról alkotott nézeteit, mennyire mozdítja el őket a gyermekközpontúság irányába, ugyanakkor ajánlott lenne a kutatást egy nagyobb mintára kiterjeszteni, mivel jelen tanulmány alapját képező kutatás kislétszámú hallgatói mintán alapul, így a megfogalmazott következtetéseket óvatosan kell kezelnünk.

A kutatás eredményeként azt a javaslatot fogalmazhatjuk meg a tanítóképzés számára, hogy tudatosítsa a hallgatókban a biztonságos tanulói környezet kialakításához szükséges alapkompetenciák fontosságát különösen a kisiskolásokkal való foglalkozás során. A magas szintủ szaktárgyi, tanítással kapcsolatos kompetenciák mellett legalább olyan fontos a gyermekről alkotott tudás, illetve a különböző személyiségbeli jellemzők kialakítása: a gyermekszeretet, kedvesség, empátia, nyitottság, segítőkészség, igazságosság, hitelesség.

\section{Irodalomjegyzék}

Diaconu, Mihai (2002): Competenţele profesiei didactice. In. Gliga, Lucia (ed.) Standardele profesionale pentru profesia didactică. Ministerul Educaţiei şi Cercetării, Consiliul Naţional pentru pregătirea profesorilor, Bucureşti, 26-35.

Falus Iván (1998): A pedagógus. In. Falus Iván (ed.) Didaktika. Nemzeti Tankönyvkiadó, Budapest, 97-114.

Falus Iván (2001): Gondolkodás és cselekvés a pedagógus tevékenységben. In. Báthory Zoltán - Falus Iván (ed.): Tanulmányok a neveléstudomány köréböl. Osiris Kiadó, Budapest, 213-134.

Falus Iván (2005): Képesítési követelmények - kompetenciák - sztenderdek. in: Pedagógusképzés 2005.1, 5-15.

Falus Iván (2006): A tanári tevékenység és a pedagógusképzés új útjai. Gondolat Kiadó, Budapest

Falus Iván, Kimmel Magdolna (2003): A portfólió. Oktatás-módszertani Kiskönyvtár, Gondolat Kiadó, Budapest

Györgyiné Koncz Judit (2005): Pályaismeret, pályaorientáció. Károli Egyetemi Kiadó, Budapest

Iucu, Romiţă, Pănişoara, Ovidiu (1999): Formarea personalului didactic - raport de cercetare 1. Proiectul de reformă al învăţământului preuniversitar - Consiliul Naţional pentru Pregătirea Profesorilor, Bucureşti

Iucu, Romiţă, Pănişoara, Ovidiu (2000): Formarea personalului didactic - raport de cercetare 2. Proiectul de reformă al învăţământului preuniversitar - Consiliul Naţional pentru Pregătirea Profesorilor, Bucureşti

Mészáros István, Németh András, Pukánszky Béla (2000): Bevezetés a pedagógia és az iskoláztatás történetébe. Osiris Kiadó, Budapest 
Nagy József (2000): XXI. század és nevelés. Osiris Kiadó, Budapest

Nahalka István (1998): A tanulás. In. Falus Iván (ed.) Didaktika. Nemzeti Tankönyvkiadó, Budapest, 117-158.

Nikitscher Péter (2015): Milyen a jó pedagógus? - Elvárások és az érzékelt valóság egy nagymintásdiákkutatás eredményei alapján. Educatio. 24. évf. 1. sz. 129-139. http://epa.oszk.hu/01500/01551/00071/pdf/EPA01551_ecucatio_2015_1_129-139.pdf (2020.11.22)

Păun, Emil 2002: Profesionalizarea activităţii didactice. In: Lucia Gliga (ed.) Standardele profesionale pentru profesia didactică. Ministerul Educaţiei şi Cercetării, Consiliul Naţional pentru pregătirea profesorilor, Bucureşti, 20-23.

Sallai Éva (1996): Tanulható-e a pedagógusmesterség? Veszprémi Egyetemi Kiadó, Veszprém

Szabó-Thalmeiner Noémi (2009): Metszet. Státus Kiadó, Csíkszereda

Szabó-Thalmeiner Noémi (2012): A pedagógusképző oktató. In. Fazakas Emese, Fóris-Ferenczi Rita (eds.): „Ezernyi füszál zeng tücsökzenét...”. Egyetemi Mühely Kiadó, Bolyai Társaság, Kolozsvár, 282-289.

Vekerdy Tamás (2004): Gyermekközpontú-e az iskola? Új Pedagógiai Szemle. április-május, Országos Közoktatási Intézet. http://epa.oszk.hu/00000/00035/00081/2004-04-ko-VekerdyGyermekkozpontu.html. (2019.01.18.)

\section{Szerző}

Szabó-Thalmeiner Noémi, Babeș-Bolyai University, Satu Mare (Románia) E-mail: szabothnoemi@yahoo.com 